\title{
Purification, characterization of $\alpha$-galactosidase from a novel Bacillus megaterium VHM1, and its applications in the food industry
}

\author{
Aravind Gouda G. Patil ${ }^{1}$, Naganagouda V. Kote ${ }^{2 *}$, A. C. Manjula ${ }^{3}$, T. Vishwanatha ${ }^{4}$ \\ ${ }^{1}$ Department of Allied Health Sciences, BLDE Deemed to be University, Vijayapura, India. \\ ${ }^{2}$ Department of Biochemistry, Maharanis Science College for Women, Bangalore, India. \\ ${ }^{3}$ Department of Sericulture, Maharanis Science College for Women, Bangalore, India. \\ ${ }^{4}$ Department of Microbiology, Maharanis Science College for Women, Bangalore, India.
}

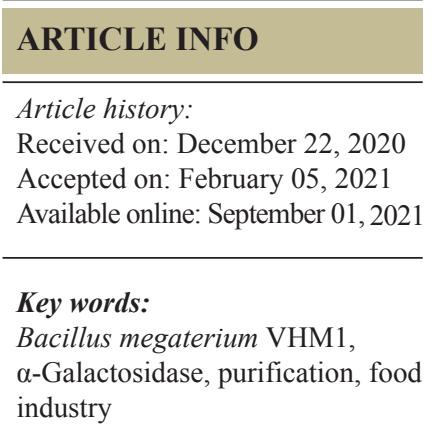

\begin{abstract}
An extracellular thermostable $\alpha$-galactosidase from Bacillus megaterium VHM1 was purified 94.26-fold by precipitation with ethanol, followed by sequential column chromatography with DEAE-Sephacel and $\mathrm{G}_{75}$ column. The purified enzyme was homogeneous on sodium dodecyl sulfate polyacrylamide gel electrophoresis (SDSPAGE). It was found to be a monomeric protein with a molecular weight of about $66 \mathrm{kDa}$. The purified enzyme showed optimum activity in p-nitrophenyl $\alpha$-D-galactopyranoside (PNPG) at $\mathrm{pH} 7.0$ and a temperature of $60^{\circ} \mathrm{C}$. The enzyme was thermostable, showing complete activity even after heating at $55^{\circ} \mathrm{C}$ for 60 minutes. The substrate specificity of $\alpha$-galactosidase on PNPG, ortho-Nitrophenyl- $\beta$-galactoside, and raffinose was investigated and $K_{\mathrm{m}}$ was found to be $0.508,0.529$, and $5.0 \mathrm{mM}$ and $V_{\max }$ was $3.492,4.287$, and $14.20 \mu \mathrm{mol} / \mathrm{ml} / \mathrm{minute}$, respectively. Among the metal ions and reagents tested, $\mathrm{Hg}^{2+}, \mathrm{Cu}^{2+}$, and $\mathrm{Ag}^{2+}$ strongly inhibited the $\alpha$-galactosidase activity, and ethylenediaminetetraacetic acid showed no effect on enzymes. The present study supports the application of $\alpha$-galactosidase from B. megaterium VHM1 as a potent enzyme in the food processing industry.
\end{abstract}

\section{INTRODUCTION}

$\alpha$-Galactosidase (EC.3.2.1.22) is an exogalactosidase that catalyzes the hydrolysis of terminal $\alpha-1-6$-linked-D-galactose residues from simple galactose containing oligosaccharides such as melibiose, raffinose, stachyose, and verbascose, as well as more complex polysaccharides including galactomannans [1]. $\alpha$-Galactosidases are of particular interest in view of their many potential biotechnological and medicinal applications. The most important industrial applications being in beet sugar industry [2], soy food processing [3], animal feed processing [4], and in pulp and paper industries [5]. $\alpha$-Galactosidase is also used for the removal of a qualitative proportion of galactose moieties from guar gum in order to improve the gelling prosperities of the polysaccharides and to make them comparable to those of locust been gum [6]. Furthermore, galacto-oligosaccharides produced by the transfer reaction of $\alpha$-galactosidase can be used as a prebiotic in functional food [7]. An increased interest in $\alpha$-galactosidase can be seen in

\footnotetext{
*Corresponding Author

Naganagouda V. Kote, Department of Biochemistry, Maharani's Science College for Women, Bangalore, India.E-mail:kngouda@gmail.com
}

human medicine as it is used in blood group transformation [8], treatment of Fabry's disease, and in xenotransplantation [9]. Some of the $\alpha$-galactosidases are also known to have trans-glycosidase activity $[10,11]$.

$\alpha$-Galactosidases have been isolated from various sources. Most of the $\alpha$-galactosidases have been extensively isolated and purified from fungal sources [12,13]. Bacillus megaterium is Gram-positive, mainly aerobic spore-forming bacterium found in various habitats, from soil to sea water. The organism is industrially employed as it possesses some very useful and unusual enzymes and has a high capacity for the production of exoenzymes. The seven plasmids of B. megaterium strain QM B1552 contain several unusual metabolic genes that may be useful in bioremediation. Altogether, a "toolbox" of hundreds of genetically characterized strains, genetic methods, vectors, hosts, and genomic sequence makes $B$. megaterium an ideal organism for industrial and environmental applications [14]. Sindhu et al. [15] reported on the production of cellulose-free xylanase from $B$. megaterium by solid-state fermentation for biobleaching of pulp. Bacillus. megaterium also produced $\beta$-amylase by solid state fermentation using starch waste [16]. Bacillus sp. JF2 strain produced extracellular thermostable $\alpha$-amylase (EC 3.2.1.1) 
and intracellular $\alpha$-galactosidase (EC 3.2.1.22) [17]. Intracellular $\alpha$-galactosidase production was expressed by the growthassociated model and relationship equation between the substrate and cell growth, two enzyme productions were also defined, and all constants were defined.

Thermostable enzymes are gaining wide and excellent applications in industrial sectors that take advantage of their function of high temperature. Bacillus. megaterium VHM1 has been found to secrete extracellular thermostable $\alpha$-galactosidase. Here we report on the purification and characterization of $\alpha$-galactosidase from a novel strain B. megaterium VHM1.

\section{MATERIALS AND METHODS}

\subsection{Isolation and Characterization of the Bacteria}

A strain of alkalophilic bacterium B. megaterium VHM1, producing extracellular $\alpha$-galactosidase, was isolated from sugar cane industrial waste samples near Bijapur (Karnataka, India). The nutrient broth used for isolation of bacterium was supplemented with defatted soya flour extract at $50^{\circ} \mathrm{C}$ and $\mathrm{pH}$ was adjusted to 7.5. The isolate was maintained on nutrient agar slants containing the following (per liter of distilled water): peptone, $10 \mathrm{~g}$; yeast extract, $10 \mathrm{~g}$; and guar gum, $5 \mathrm{~g}$. The isolate was identified on the basis of morphological, physiological, and biochemical tests as described in Bergey's Manual of Systematic Bacteriology [18]. The partial 16S rDNA nucleotide sequences were determined as previously described Kim et al. [19]. The 16S rDNA was amplified by polymerase chain reaction (PCR) $\left(94^{\circ} \mathrm{C}\right.$ for 5 minute, 30 cycles consisting of $94^{\circ} \mathrm{C}$ for 30 seconds, $55^{\circ} \mathrm{C}$ for 30 seconds, and $72^{\circ} \mathrm{C}$ for 90 seconds), followed by a terminal incubation at $72^{\circ} \mathrm{C}$ for 10 minutes) with universal $16 \mathrm{~S}$ rDNA F and $\mathrm{R}$ primers from isolated strains. The PCR amplified product was purified and nucleotide sequences were determined at SolGent Co. Ltd (Taejeon, Korea) with an automated sequencing apparatus (ABI PRISM 377, PE Biosystems Inc.) using $16 \mathrm{~S}$ rDNA F/R primers. The sequences thus generated were deposited in National Center for Biotechnology Information (NCBI) nucleotide sequence database under accession no. FJ 613521. The 16S rDNA sequences of isolated strains were compared with the DNA sequences deposited in NCBI and identified based on sequence homology. Phylogenetic and molecular evolutionary analyses were conducted using MEGA version 4 [20].

\subsection{Enzyme Production}

The medium used for production of $\alpha$-galactosidase was mineral salt guar gum medium $(0.5 \%$ guar gum and $0.5 \%$ peptone containing mineral salt medium). The sterilized Erlenmeyer flasks $(250 \mathrm{ml}$ capacity containing $50 \mathrm{ml}$ of medium) were inoculated with 24hour grown culture of $B$. megaterium VHM1. Fermentation was carried out on rotary orbital shaker at $120 \mathrm{rpm}$ at $40^{\circ} \mathrm{C}$ for 26 hours. After 26 hours of submerged fermentation, the broth was centrifuged at $10,000 \mathrm{rpm}$ for 10 minutes. The supernatant is taken as crude enzyme source and was kept at $4{ }^{\circ} \mathrm{C}$ until further studies.

\subsection{Enzyme Assay}

$\alpha$-Galactosidase activity was carried out according to the method of Dey and Pridham [1]. $1 \mathrm{ml}$ of reaction mixture contains 100 $\mu 1$ of suitably diluted enzyme, $50 \mu \mathrm{l}$ of $10 \mathrm{mM}$ chromogenic substrate (p-nitrophenyl $\alpha$-D-galactopyranoside, PNPG), and 850 $\mu 1$ of $0.2 \mathrm{mM}$ phosphate buffer ( $\mathrm{pH} \mathrm{7.5)}$ at $50^{\circ} \mathrm{C}$ for 10 minutes. The reaction was terminated by adding $2 \mathrm{ml}$ of $0.2 \mathrm{M}$ sodium carbonate solution. The amount of p-nitrophenol released was estimated from absorbance at $405 \mathrm{~nm}$. Enzyme activity was expressed as the amount of enzyme required to liberate $1 \mu \mathrm{mol}$ of product per minute under the assay conditions.

\subsection{Protein Assay}

Protein concentration was determined by the method of Lowry et $a l$. [21]. Fractions obtained during the purification procedure were screened for protein content by UV absorbance spectrophotometer (Elico India Ltd) at $280 \mathrm{~nm}$.

\subsection{Purification of $\alpha$-Galactosidase}

The precooled ethanol was added slowly to the crude enzyme extract with constant stirring to give a concentration of $1: 1.5$ $(v / v)$ and this solution was kept at $4^{\circ} \mathrm{C}$ for 6 hours, centrifuged at $12,000 \times \mathrm{g}$ for 20 minutes and the supernatant were discarded. The precipitate was dissolved in Tris-Hcl buffer $(0.05 \mathrm{M} \mathrm{pH}$ 7.5) and dialyzed against the same buffer at $10^{\circ} \mathrm{C}$ for 12 hours, and then used for further purification. The dialyzed enzyme was loaded onto a DEAE-Sephacel column $(2.3 \times 10 \mathrm{~cm})$ equilibrated with phosphate buffer $(0.05 \mathrm{M} ; \mathrm{pH} 7.5)$ and the column was washed with the same buffer. The enzyme bound to DEAE-Sephacel was eluted with linear gradient of $0.5 \mathrm{M}$ $\mathrm{NaCl}$ in an equilibration buffer $(50 \mathrm{mM} ; \mathrm{pH} 7.5)$; fractions were collected at the flow rate of $40 \mathrm{ml} /$ hour using a peristaltic pump p-1 (Pharmacia); and fractions $(2.5 \mathrm{ml})$ were collected using the fractional collector. All the fractions were checked for protein $\left(\mathrm{A}_{280}\right)$ and $\alpha$-galactosidase activity $\left(\mathrm{A}_{450}\right)$. The fractions having maximum enzyme activity were pooled, concentrated, and stored at $4^{\circ} \mathrm{C}$ for further purification. $\mathrm{G}_{75}$ gel-filtration matrix in a column $(1.8 \times 50 \mathrm{~cm})$ was equilibrated with phosphate buffer $(50 \mathrm{mM}$; $\mathrm{pH}$ 7.5). The concentrated enzyme obtained after ion exchange chromatography was loaded on the column and allowed to enter the gel. The protein was then eluted with equilibration buffer. The flow rate was adjusted to $32 \mathrm{ml} /$ hour using peristaltic pump p-1(Pharmacia). Fractions $(2.5 \mathrm{ml})$ were collected using fractional collector. The entire fractions were checked for protein and enzyme activities. The fractions showing $\alpha$-galactosidase activity were pooled, concentrated, and dialyzed. This dialyzed enzyme solution was then used as for purified enzyme preparation.

\subsection{Electrophoresis and Zymogram Analysis}

The purity of the enzyme was checked using $10 \%$ denaturating sulfateSDS-PAGE under reducing conditions. The polyacrylamide gel was prepared by the method of Laemmli [22]. The Mr of the purified $\alpha$-galactosidase was calculated based on the relative mobility of the molecular mass markers from GENE, Bangalore (phosphorylase $\mathrm{B}=97.4 \mathrm{kDa}$, ovalbumin $=43 \mathrm{kDa}$, carbonic anhydrase $=29 \mathrm{kDa}$, soybean trypsin inhibitors $=20.05 \mathrm{kDa}$, and lysozyme $=14.3 \mathrm{kDa}$ ). For zymogram analysis, the SDS-PAGE gel was treated with Triton $\mathrm{X}$ for 10 minutes to remove SDS; the triton $\mathrm{X}$ treated gel was 

and its applications in the food industry 2021;9(05):13-19

incubated with $2 \% \mathrm{~Pb}\left(\mathrm{NO}_{3}\right)_{2}+1 \mathrm{mM} \mathrm{MgCl} 2+$ p-nitrophenyl $\alpha$-D-galactopyransoside + acetate buffer $\mathrm{pH} 6.0$ for 10 minutes. After 10 minutes, $2 \%$ glacial acetic acid was added to terminate the reaction for 10 minutes and washed with distilled water. After that, diluted ammonium sulfide was added and kept for 10 minutes and then washed with distilled water. Black color band corresponds to $\alpha$-galactosidase activity. Here, the phosphate ions liberated from PNPG will react with ammonium sulfide and $\mathrm{MgCl}_{2}$ to produce colored bands.

\subsection{Optimum pH and Stability}

The optimum $\mathrm{pH}$ of $\alpha$-galactosidase was determined by assaying $\alpha$-galactosidase activity using a standard assay method over a $\mathrm{pH}$ range of 4.0-9.0 using either $50 \mathrm{mM}$ acetate buffer ( $\mathrm{pH} 4.0-6.0$ ), $50 \mathrm{mM}$ phosphate buffer ( $\mathrm{pH}$ 6.0-7.5), or barbitone buffer $(\mathrm{pH}$ 8.0-9.0). Enzymatic activities at different $\mathrm{pH}$ were expressed as relative values (\%) with reference to $100 \%$ activity at the optimal $\mathrm{pH}$. The $\mathrm{pH}$ stability was determined by pre-incubating the enzyme in $50 \mathrm{mM}$ acetate buffer ( $\mathrm{pH} 4.0-6.0$ ), $50 \mathrm{mM}$ phosphate buffer ( $\mathrm{pH}$ 6.0-7.5), or barbitone buffer $(\mathrm{pH} 8.0-9.0)$.for a period of 2 hours at $55^{\circ} \mathrm{C}$. Small aliquots were withdrawn from all the samples and residual enzyme activity was determined by standard assay methods.

\subsection{Optimum Temperature and Stability}

The optimum temperature of $\alpha$-galactosidase was determined by carrying out assays at temperatures ranging from $30^{\circ} \mathrm{C}$ to $75^{\circ} \mathrm{C}$. Thermal stability of the enzyme was determined by incubating the enzyme at temperatures ranging from $65^{\circ} \mathrm{C}$ to $75^{\circ} \mathrm{C}$ for several time periods. The residual activity of the enzyme was estimated under standard assay conditions.

\subsection{Determination of Kinetic Parameters $\left(K_{\mathrm{m}}\right.$ and $\left.V_{\max }\right)$}

The kinetic parameters $\left(K_{\mathrm{m}}\right.$ and $\left.V_{\max }\right)$ were determined with the use of varying concentrations of artificial substrates PNPG and natural substrates raffinose in a phosphate buffer of $\mathrm{pH} 7.0$ and incubated at $60^{\circ} \mathrm{C}$ for 10 minutes. When PNPG was used, the reaction (assay) was arrested by adding $3 \mathrm{ml}$ of $0.2 \mathrm{M}$ sodium carbonate solution and the absorbance was measured at 405 $\mathrm{nm}$. In case of raffinose, the reaction was arrested by adding 1 $\mathrm{ml}$ of alkaline copper reagent. Test tubes were kept in a boiling water bath for 20 minutes. $1 \mathrm{ml}$ of arsenomolybdate reagent was added and the absorbance was read at $540 \mathrm{~nm}$ [23]. The kinetic parameters were determined by the plot method Lineweaver and Burk [24].

\subsection{Effect of Inhibitors and Metal Ions on $\alpha$-Galactosidase}

The sensitivity of the enzyme to metals was examined by running the standard $\alpha$-galactosidase assay at optimum temperature and $\mathrm{pH}$. Metal ions $\left(\mathrm{AgNO}_{3}, \mathrm{CaCl}_{2}, \mathrm{Cu} \mathrm{SO}_{4}, \mathrm{HgCl}_{2}\right.$, $\mathrm{MgCl}_{2}, \mathrm{MnSO} 4, \mathrm{NiCl}_{2}$, and $\mathrm{ZnSO}_{4}$ ) were dissolved to a final concentration of $10 \mathrm{mM}$ in $50 \mathrm{mM}$ phosphate buffer of $\mathrm{pH}$ 7.0. To determine the effect of inhibitors on $\alpha$-galactosidase, the enzyme was pre-incubated with final concentrations of $10 \mathrm{mM} 1$, 10-Phenthraline; N-bromosuccinamide, PMSF, Mercaptoethonol, ethylenediaminetetraacetic acid (EDTA), and urea. After 30 minutes of pre-incubation, the reaction was initiated by addition of $1 \mathrm{mM}$ PNPG.

\section{RESULTS AND DISCUSSION}

\subsection{Purification of $\alpha$-Galactosidase}

The enzyme purification protocol is summarized in Table 1. $\alpha$-Galactosidase was purified 94.26 -fold with $42.20 \%$ yield from the crude enzyme extract. First, the proteins in the crude extract were precipitated with chilled ethanol at 1:1.5 $(\mathrm{v} / \mathrm{v})$. This step achieved a 4.11 -fold enzyme purification, and $90.05 \%$ of the enzyme could be recovered. Then, the concentrated enzyme preparation was fractionated by anionic exchange chromatography using a DEAESephacel column, in which the enzyme was eluted with linear gradient of $0.5 \mathrm{M} \mathrm{NaCl}$ in equilibration buffer $(50 \mathrm{mM} ; \mathrm{pH} 7.5)$. The elution profile is shown in Figure 1. The remaining protein contaminants were removed by gel filtration using $\mathrm{G}_{75}$ (Fig. 2). The fractions with maximal enzyme activity were collected and further examined for purity by gel electrophoresis.

Earlier, purification of fungal $\alpha$-galactosidase was achieved by multistep purification procedures, which were tedious and timeconsuming [25-27]. However, the purification scheme employed here is relatively simple and highly reproducible. Garro et al. [28] purified $\alpha$-galactosidase from Lactobacillus ferementum up to homogeneity using three steps, ammonium sulfate precipitation, gel filtration, and ion exchange chromatography, to the yield of $5.50 \%$ and purification fold of $21.03 \%$. Gote et al. [29] purified $\alpha$-galactosidase from Bacillus stearothermophilus using three steps amicon concentration, followed by ultrafiltration, alcohol precipitation, and hydrophobic interaction chromatography to the yield of $44.6 \%$ and purification fold of $369 \%$.

\subsection{Electrophoretic Analysis of $\alpha$-Galactosidase on SDS-PAGE}

After simple three purification steps, SDS-PAGE of the final enzyme preparation showed a single band. The molecular weight

Table 1: Summary of the purification of $\alpha$-galactosidase from B. megaterium VHM1.

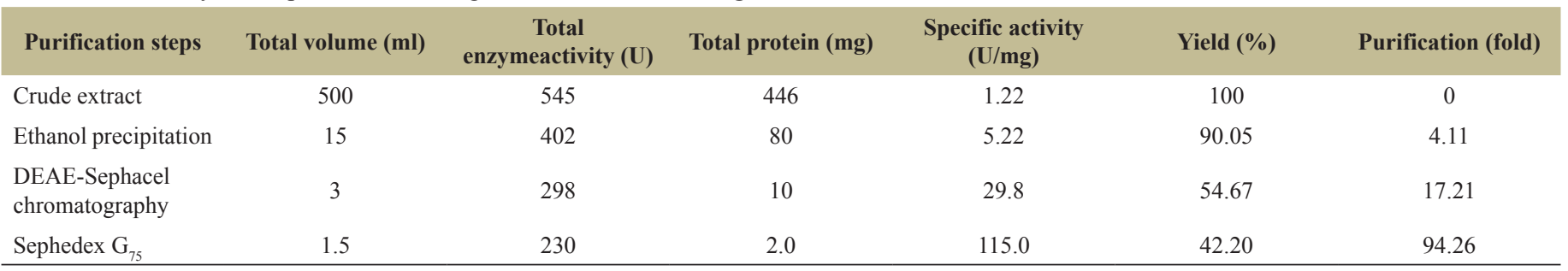




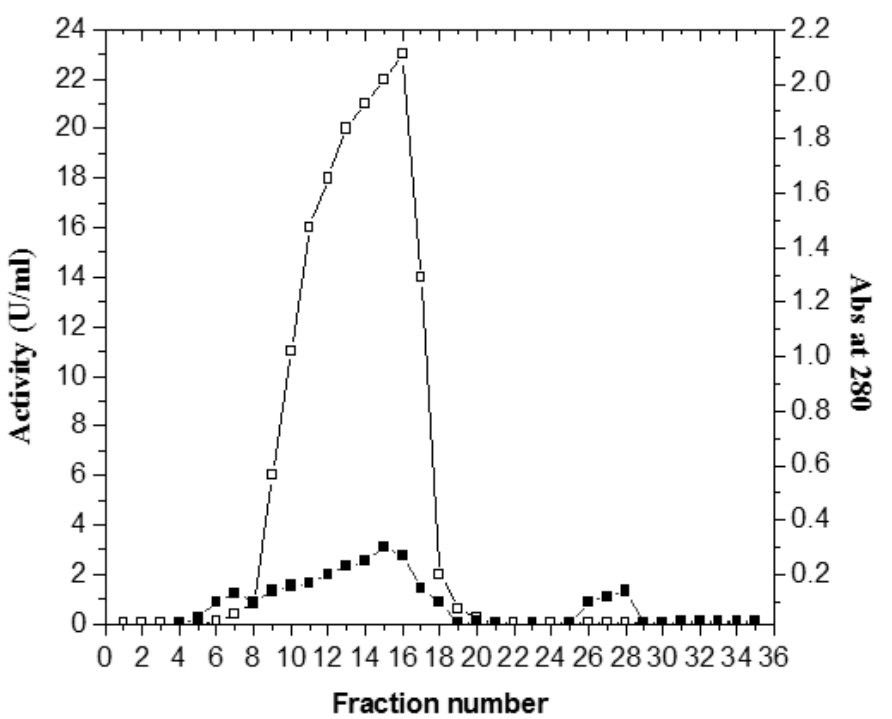

Figure 1. Elution profile DEAE-Sephacel column chromatography of $\alpha$-galactosidase B. megaterium VHM1 - $-\alpha$-Galactosidase activity; - - -Absorbance at $280 \mathrm{~nm}$.

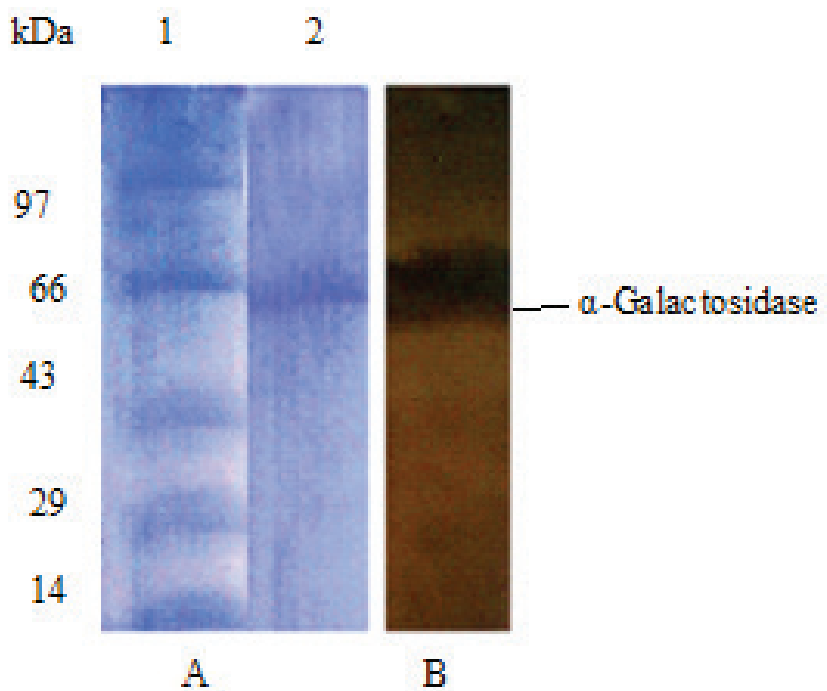

Figure 2: SDS-PAGE of purified $\alpha$-galactosidase. (A) Lane 1: molecular weight markers and Lane 2: purified $\alpha$-galactosidase. (B) Activity staining of $\alpha$-galactosidase.

of the purified enzyme by SDS-PAGE was between 60 and 64 KDa (Fig. 3). Similar to our results, the molecular weights of $\alpha$-galactosidase B. stearothermophilus and Debromyces hansenii were in range from 57 to $80 \mathrm{kDa}[29,30]$.

\subsection{Effect of pH on $\alpha$-Galactosidase Activity and Stability}

Figure 4 shows that purified $\alpha$-galactosidase from $B$. megaterium VHM1 was considerably active from $\mathrm{pH} 6.0$ to 9.0. Optimum $\mathrm{pH}$ of $\alpha$-galactosidase is 7.0. The purified $\alpha$-galactosidase showed broader stability over a $\mathrm{pH}$ range of $4.5-8.5$ (Fig. 5). The enzyme exhibited $65 \%$ residual activity at $\mathrm{pH} 4.5$ and $75 \%$ at $\mathrm{pH} 8.0$. From the literature, it is evident that $\alpha$-galactosidase from $B$. stearothermophilus has an optimum activity at neutral to basic

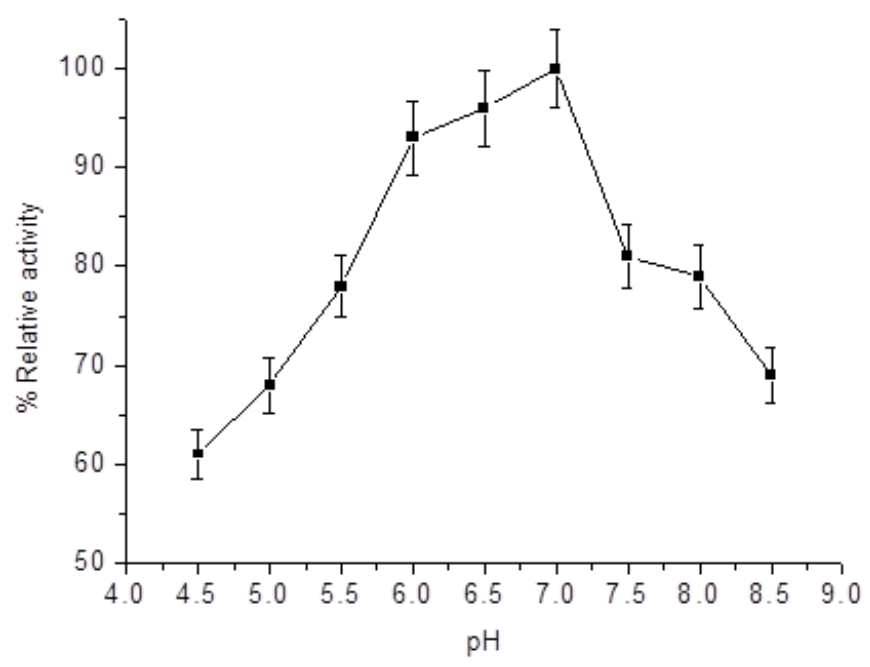

Figure 3. Effect of $\mathrm{pH}$ on the activity of $\alpha$-galactosidase from $B$. megaterium VHM1.

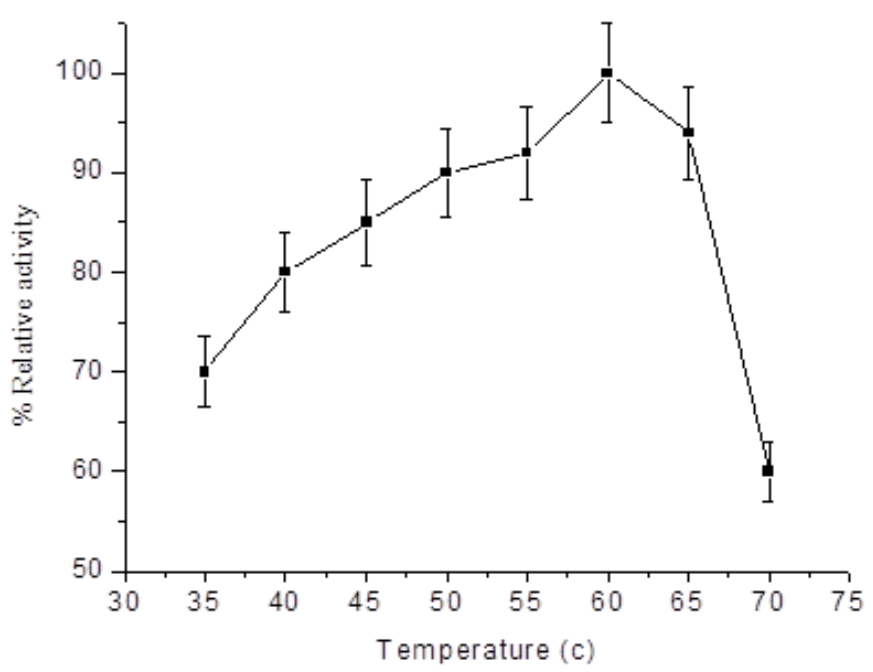

Figure 4. Effect of temperature on activity of $\alpha$-galactosidase activity from $B$. megaterium VHM1.

side. $\alpha$-Galactosidase from $B$. stearothermophilus was optimally active between $\mathrm{pH} 7$ and 7.5, and stable in pH 4.8 [31-33]. Li et al. [34] reported Bacillus spp. JF2 $\alpha$-galactosidase optimal activity at $\mathrm{pH} 7.2$, whereas in case of fungal $\alpha$-galactosidase it showed optimal activity toward acidic $\mathrm{pH}(4.0-6.0)$ [30,35].

\subsection{Effect of Temperature on Activity and Stability of $\alpha$-Galactosidase}

Figure 5 shows the temperature optima for $B$. megaterium VHM1 $\alpha$-galactosidase. The enzyme maximally hydrolyzed PNPG at $60^{\circ} \mathrm{C}(\mathrm{pH} 7.0)$. Figure 4 shows a thermostability profile of $\alpha$-galactosidase. It is clear from Figure 4 that the enzyme is $100 \%$ stable up to 60 minutes at $55^{\circ} \mathrm{C}$. More than $65 \%$ activity is retained up to 40 minutes at $65^{\circ} \mathrm{C}$. The enzyme was thermostable with a half-life of 50 minutes at $65^{\circ} \mathrm{C}$. After 50 minutes incubation at $65^{\circ} \mathrm{C}$, enzyme activity decreased rapidly. Li et al. [34] reported 

and its applications in the food industry 2021;9(05):13-19

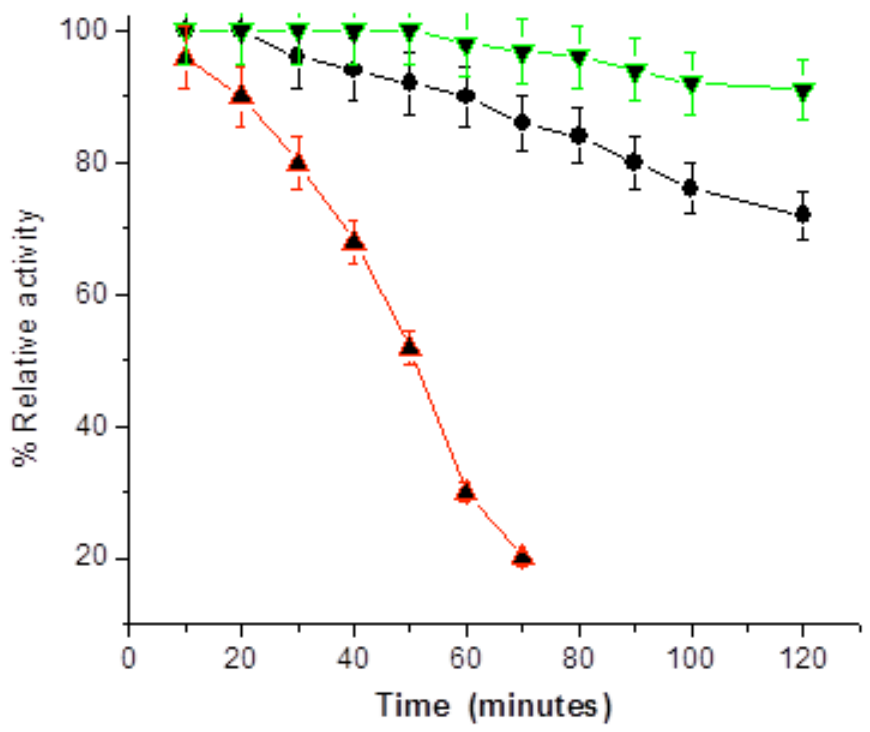

Figure 5. Effect of temperature stability on $\alpha$-galactosidase from $\mathrm{B}$. megaterium VHM1, $\boldsymbol{\Delta} 65^{\circ} \mathrm{C}, \bullet 60^{\circ} \mathrm{C}, \boldsymbol{\nabla} 55^{\circ} \mathrm{C}$

Table 2: $K_{m}$ and $V_{\max }$ values of $B$. megaterium VHM1 $\alpha$-galactosidase.

\begin{tabular}{lccc}
\multicolumn{1}{c}{ Substrates } & Relative activity (\%) & $\boldsymbol{K}_{\mathbf{m}(\mathbf{m M})}$ & $\boldsymbol{V}_{\max (\mu \mathrm{mol} / \mathrm{m} / \mathbf{m i n u t e})}$ \\
PNPG & 100 & 0.508 & 3.492 \\
ONPG & 96 & 0.529 & 4.287 \\
Raffinose & 80 & 5.0 & 14.20 \\
Guar gum & 76 & - & - \\
Locust bean gum & 60 & - & - \\
\hline
\end{tabular}

$\alpha$-galactosidase from Bacillus JF2 spp. optimal activity at $55^{\circ} \mathrm{C}$ and thermostability at $60^{\circ} \mathrm{C}$ for 40 minutes. Garro et al. [28] reported $\alpha$-galactosidase from $L$. ferementum optimal temperature was $45^{\circ} \mathrm{C}$ and half-life of the enzyme was 30 minutes at $60^{\circ} \mathrm{C}$. Gote et al. [32] reported $B$. stearothermophilus optimal $\alpha$-galactosidase activity at $65^{\circ} \mathrm{C}$ and its half-life inactivation $\left(t \frac{1 / 2}{)}\right)$ at $70^{\circ} \mathrm{C}$ for 30 minutes. Fridjonsson et al. [36] reported $\alpha$-galactosidase from $B$. stearothermophilus optimal temperature at $70^{\circ} \mathrm{C}$ and $t$ $1 / 2$ of the enzyme was 19 hours at $70^{\circ} \mathrm{C}$. Other reports from $B$. stearothermophilus showed optimal temperature at $70^{\circ} \mathrm{C}[29,31]$.

\subsection{Substrate Specificity and Determination of Kinetic Parameters}

Kinetic parameters $K_{\mathrm{m}}$ and $V_{\max }$ of $B$. megaterium VHM1 had higher affinity toward PNPG $\left(K_{\mathrm{m}} 0.508 \mathrm{mM}\right)$ than that of orthoNitrophenyl- $\beta$-galactoside (ONPG) $(0.529 \mathrm{mM})$. Other natural substrates also had a higher $K_{\mathrm{m}}$ value. The relative substrate specificity toward synthetic and natural galactosidase is in the order $\mathrm{PNPG}>\mathrm{ONPG}>$ Raffinose $>$ Guargum (Table 2 ). The kinetic study revealed that enzyme prefers synthetic as well as natural polysaccharides. Therefore, enzyme is applicable in the food processing industry for elimination of flatulence causing factors in legume-based foods. In the literature, $\alpha$-galactosidase from different organisms has different $K_{\mathrm{m}}$ and $V_{\max }$ values. King et al. [37] reported
Table 3: Effect of inhibitors and metal ions on $\alpha$-galactosidase from B. megaterium VHM1.

\begin{tabular}{lc}
\multicolumn{1}{c}{ Inhibitors/metal ions } & Residual activity $(\mathbf{\%})$ \\
None & 100 \\
N-bromosuccinamide & 000 \\
PMSF & 100 \\
EDTA & 100 \\
1-10-Phenanthroline & 100 \\
$\mathrm{Mercaptoethanol}^{2+}$ & 100 \\
$\mathrm{Mg}^{2+}$ & 105 \\
$\mathrm{Hg}^{2+}$ & 0 \\
$\mathrm{Zn}^{2+}$ & 69 \\
$\mathrm{Cu}^{2+}$ & 0 \\
$\mathrm{Ag}^{2+}$ & 0 \\
$\mathrm{Ni}^{2+}$ & 89 \\
$\mathrm{Co}^{2+}$ & 94 \\
$\mathrm{Mn}^{2+}$ & 100 \\
$\mathrm{Ca}^{2+}$ & 82 \\
\hline
\end{tabular}

Thermoanaerobacterium Polysacchrolyticum $\alpha$-galactosidase $K_{\mathrm{m}}$ value for PNPG was $0.38 \mathrm{mM}$ and raffinose was $16.4 \mathrm{mM}$.

\subsection{Effect of Inhibitors and Metal Ions on $\alpha$-Galactosidase Activity}

The effect of different inhibitors and metal ions on $\alpha$-galactosidase activity is depicted in Table 3. Among the inhibitors tested, EDTA and 1,10 , phenantherene did not inhibit the $\alpha$-galactosidase activity and this indicates that $\alpha$-galactosidase is not a metalloenzyme. Inhibition of $\alpha$-galactosidase from $B$. megaterium VHM1 by $\mathrm{N}$-bromosuccinamide indicates that role of tryptophan at or near the active site. Among the metal ions tested on $\alpha$-galactosidase activity, $\mathrm{Hg}^{2+}, \mathrm{Cu}^{2+}$, and $\mathrm{Ag}^{2+}$ were strongly inhibited. Inhibition of $\mathrm{Hg}^{2+}$ ions suggested that the enzyme contains sulfahydryl group. Similar to our report, Garro et al. [28] reported complete inhibition of $\alpha$-galactosidase in the presence of $\mathrm{Hg}^{+}$and the enzyme was not inhibited by mercaptoethanol and EDTA. Fridjonsson et al. [34] reported that $B$. stearothermophilus from $\alpha$-galactosidase is inhibited by $\mathrm{Hg}^{2+}$ and $\mathrm{Cu}^{2+}$ metal ions. King et al. [37] reported that T. polysacchrolyticum $\alpha$-galactosidase is completely inhibited by $\mathrm{Hg}^{2+}$ ions, whereas fungal $\alpha$-galactosidase was strongly inhibited by $\mathrm{Ag}^{2+}, \mathrm{Hg}^{2+}$, and metal ions $[33,38]$.

\section{CONCLUSION}

The present study reveals that the application of thermostable novel $\alpha$-galactosidase from $B$. megaterium VHM1 as a potent enzyme in the degradation of raffinose family oligosaccharides and food processing industry.

\section{ACKNOWLEDGMENTS}

Author Aravind Goud G Patil is thankful to the Council of Scientific and Industrial Research (CSIR), New Delhi, for 
providing financial support in the form of Senior Research Fellowship (SRF).

\section{AUTHOR CONTRIBUTIONS}

All authors made substantial contributions to conception and design, acquisition of data, or analysis and interpretation of data; took part in drafting the article or revising it critically for important intellectual content; agreed to submit to the current journal; gave final approval of the version to be published; and agree to be accountable for all aspects of the work. All the authors are eligible to be an author as per the international committee of medical journal editors (ICMJE) requirements/guidelines.

\section{CONFLICTS OF INTEREST}

The authors report no financial or any other conflicts of interest in this work.

\section{ETHICAL APPROVALS}

This study does not involve experiments on animals or human subjects.

\section{REFERENCES}

1. Dey PM, Pridham JB, Biochemistry of $\alpha$-galactosidase. Adv Enzymol 1972;36:91.

2. Linden JC. Immobilized $\alpha$-D--galactosidase in sugar beet industry. Enzyme Microb Technol 1982;4:130-6.

3. Kotwal SM, Gote MM, Sainkar SR, Khan MI, Khire JM, Production of $\alpha$-galactosidase by thermophillic fungus Humicola sp. In solidstate fermentation and its application in soymilk hydrolysis. Process Biochem 1998;33:337-43.

4. de Smet, Hesta M, Seynaeve M, Jonssens G, Vanrolghan P, de Wide RO. The influence of supplemented $\alpha$-galactosidase and phytase in a vegetable ratio for dogs on the digestability of organic components and phytase phosphorous. J Anim Physiol Nutr 1999;81:1-8.

5. Clarke JH, Davidson K, Rixon JE, Halstead JR, Fronsen MP, Gilbert HJ, A comparision of enzyme aided bleaching of soft wood paper pulp using combinations of xylanase, mannanase, and $\alpha$-galactosidase Appl Microbial Biotechnol 2000;53:661-7.

6. Bulpin PV, Gidley MJ, Jeffcoat R, Underwood DR. Development of a biotechnological process for the modification of galactomannan polymers with plant $\alpha$-galactosidase. Carbohydr Polym 1990;12:155-68.

7. Rezessy-Szaby JM, Nguyen QD, Bujna E, Takacs K, Kouacs M, Hoschke A, Thermomyces languinosus CBS, 395.62/b strain a rich source of $\alpha$-galactosidase enzyme. Food Technol Biotechnol 2003;41:55-9.

8. Olsson ML, Hill CA, dela Vega H, Liu QP, Stroud MR, Valdinocei J. Universal red blood cells-enzymatic conversion of blood group A and B antigens. Transfus Clin Biol 2004;11:33-9.

9. Linthorst GE, Holak CEM, Donker-koopman WE, Strigland A, Aerts JMFC. Enzyme therapy for Fabry's disease neutralizing antibodies towards agalside alpha and beta. Kidney Int 2004;66:1589-95.

10. Koizumi K, Tanimoto J, Okada Y, Hara K, Hashimoto H. Isolation and characterization of novel heterogenous branched cyclomaltooligosaccharides (Cyclodextrins) produced by transgalactosylation with $\alpha$-galactosidase from coffee bean. Carbohydr Res 1995;278:12942.

11. Dwyer B, Hu J, Madduri A, Lundberg D, Miller B, Gill J, et al. Affinity purification of human alpha galactosidase utilizing a novel small molecule biomimetic of alpha-D-galactose. Protein Expr Purif 2021;177:105752.
12. Ulezelo IV, Zaprometova OM, Microbial $\alpha$-galactosidase a (revivew). Appl Biochem Microbiol 1982;18:1-12.

13. Kote N, Manjula AC, Vishwanatha T, Patil AGG. High-yield production and biochemical characterization of $\alpha$-galactosidase produced from locally isolated Penicillium sp. Bull Natl Res Cent 2020;44:168; doi:10.1186/s42269-020-00420-x

14. Vary PS, Biedendieck R, Fuerch T, Meinhardt F, Rohde M, Deckwer $\mathrm{W}$, et al. B. megaterium - from simple soil bacterium to industrial protein production host. Appl Microbiol Biotechnol 2007;76:957-67.

15. Sindhu I, Chibber S, Capalash N, Sharma P. Production of cellulasefree xylanase from Bacillus megaterium by solid state fermentation for biobleaching of pulp. Curr Microbiol 2006;53:167-72.

16. Jin $\mathrm{F}, \mathrm{Li}$ Y, Zhang $\mathrm{C}$, Yu H. Thermostable $\alpha$-amylase and $\alpha$-galactosidase production from the thermophilic and aerobic Bacillus sp. JF strain. Process Biochem 2001;36(6):559-64.

17. Ray RR, Jana SC, Nanda G. $\beta$-amylase from Bacillus megaterium. Indian J Expt Biol 1997;35:285-8.

18. Claus D, Berkley RCW. Genus Bacillus. In: Sneath HA, Mair NS, Shrape ME (eds.). Bergey's manual of systematic bacteriology. 9th editions, Williams and Williams, Blatimore, MD, vol 2, 1104-39, 1986.

19. Kim JS, Kim JH, Ryu EK, Kim JK, Kim CKH, Wang I, et al. Versatile catabolic properties of the $T n 4371$-encoded $b p h$ pathway in Comamonas testosteroni (formerly Pseudomonas sp.) NCIMB 10643. J Microbiol Biotechnol 2004;14:302-11.

20. Tamura K, Dudley J, Nei M, Kumar S. MEGA4: molecular evolutionary genetics analysis (MEGA) software version 4.0. Mol Biol Evol 2007;24:1596-99.

21. Lowry OH, Rosenbrough NJ, Farr AL, Randall RJ. Protein estimation with then Folin-phenol reagent. J Biol Chem 1951;193:265-75.

22. Laemmli UK. Cleavage of structural proteins during the assembly of the head of Bacteriophage T4. Nature 1970;227:680-5.

23. Nelson NA. Photometric adaptation of the Somogyi method for determination of glucose. J Biol Chem 1944;153:375-78.

24. Lineweaver H, Burk D. The determination of enzyme dissociation constants. J Am Chem Soc 1934;56:658-66.

25. Adya S, Elbein AD. Glycoprotein enzymes secreted by Aspergillus niger: purification and properties of $\alpha$-galactosidase. J Bacterio 1977;129:850-6.

26. Civas A, Eberhard R, Dizet PL, Petek F. Glycosidases induced in Aspergillus tamarii (mycelial $\alpha$-d-galactosidases). Biochem $\mathrm{J}$ 1984;219:849-55.

27. Rezende ST, Guimaraes VM, RodriguesMC, Felix CR. Purification and characterization of an $\alpha$-galactosidase from Aspergillus fumigatus. Braz Arch Biol Technol 2005;48:195-202.

28. Garro MS, de Valdez GF, Oliver G, de Giori GS. Purification of $\alpha$-galactosidase from Lactobacillus fermentum. J Biotechno 1996;45:103-9.

29. Gote MM, Khan MI, Gokhale DV, Bastawde KB, Khire JM Purification, characterization and substrate specificity of thermostable $\alpha$-galactosidase from Bacillus stearothermophilus (NCIM-5146). Process Biochem 2006;41:1311-17.

30. Viana PA, Rezende ST, Marques VM, Trevizano LM, Passos FML, Oliveira MGA. Extracellular $\alpha$-galactosidase from Debaryomyces hansenii UFV-1 and its use in the hydrolysis of raffinose oligosaccharides. J Agric Food Chem 2006;54:2385-2391.

31. Delente J, Jhonson JH, Kuo MJ, O'Connors RS, Weeks LE, Production of new thermostable neutral $\alpha$-galactosidase from Bacillus stearothermophilus. Biotechnol Bioeng 1974;16:1227-43.

32. Gote M, Umalkar H, Khan I, Khire J. Thermostable $\alpha$-galactosidase from Bacillus stearothermophilus (NCIM 5146) and its application in the removal of flatulence causing factors from soymilk. Process Biochem 2004;39:1723-29.

33. Talbot G, Sygusch J. Purification and characterization of thermostanle $\beta$-mannanase and $\alpha$-galactosidase from Bacillus stearothermophilus. Appl Environ Microbiol 1990;56:3505-10. 


$$
\text { and its applications in the food industry 2021;9(05):13-19 }
$$

34. Li X, Yang P, Yan F, Zuo F, Zin F. Factors regulating production of a-galactosidase from Bacillus sp JF2. Lett Appl Microbiol 1997;25: $1-4$.

35. Shankar SK, Dhananjay SK, Mulimani VH. Purification and characterization of thermostable $\alpha$-galactosidase from Aspergillus terreus GR. Appl Biochem Biotechnol 2008;152:275-85

36. Fridjonsson O, Watzlawick H, Gehweiler A, Rohrhirsch T, Mattes R. Thermostable $\alpha$-galactosidase from Bacillus stearothermophilus NUB3621: cloning, sequencing and characterization. FEMS Microbiol Lett 1999;176:147-53.

37. King MR, White BA, Blaschek HP, Chassy BM, Mackie RI, Cann IK. Purification and characterization of a thermostable $\alpha$-galactosidase from Thermoanaerobacterium polysaccharolyticum. J Agric Food Chem 2002;50:5676-82.
38. Kotwal SM, Gote MM, Sainkar SR, Khan MI, Khire JM. Production of $\alpha$-galactosidase by thermophillic fungus Humicola sp. solid state fermentation and its application in soymilk hydrolysis. Process Biochem 1998;33:337-43.

How to cite this article:

Patil AGG, Kote NV, Manjula AC, Vishwanatha T. Purification, characterization of $\alpha$-galactosidase from a novel Bacillus megaterium VHM1 and its applications in food industry. J Appl Biol Biotech 2021; 9(05):13-19. 